\title{
The Morphology and Ecology of an Extreme Terrestrial Form of Zygnema (Zygogonium) ericetorum (Kuetz.), Hansg.
}

\author{
BY
}

\author{
F. E. FRITSCH, D.Sc. \\ With three Figures in the Text。
}

$\mathrm{T}$ HE Alga Zygnema evicetorum (Kuetz.), Hansg. has long been familiar as a form capable of inhabiting both terrestrial substrata and pieces of standing water, but until recently it had received little attention. West and Starkey ('15) have, however, in the present year, added considerably to our knowledge of the Alga in question.

The present communication is mainly concerned with a form of Zygnema evicetorum that inhabits certain bare areas on the Hindhead Common (cf. Fritsch and Salisbury, '15, p. I3I). The habitat is as inhospitable as could well be imagined and, as a result, the characteristics usually found in the terrestrial form of the Alga are developed to a very pronounced extent. Certain of these characters appear as adaptations to the habitat (see especially the third section of this paper).

Apart from what I will in the following pages refer to as the Hindhead form, I have also examined material of the ordinary terrestrial form from the foot of the scree below the cliffs of Lliwedd on the Snowdon Range, and of the aquatic form from Frensham in Surrey. For the former material I am indebted to Mr. R. J. Tabor, B.Sc., whom I have also to thank for certain details as regards its habitat.

As far as I am aware, only one other member of the Zygnemaceae occurs on terrestrial substrata, and that is Zygnema javanicum, v. Martens (De Wildeman, '97, pp. 82, 83), since $Z$. pachydermum, W. and G. S. West, has recently been stated not to be specifically distinct from $Z$. ericetorum (cf. West and Starkey, '15, p. 203). The latter species enjoys a very wide geographical distribution, having been recorded from many different parts of the world, and, in view of its apparent variability, it is not altogether out of the question that $Z$. javanicum may be another form of this ubiquitous Alga.

[Annals of Botany, Vol. XXX. No. CXVII. January, 1916.] 


\section{A. The Cell-Contents.}

The accounts as to the nature of the chloroplasts vary considerably. Schmitz ('83, pp. I8, 44) describes them as closely resembling those of other species of Zygnema. Wille ('90, p. 20), in the first edition of Engler and Prantl's 'Natuirliche Pflanzenfamilien', speaks of two axile irregular chloroplasts, occasionally coalescing (zusammenfliessend) to form an axile strand, whilst in the 'Nachträge' (Wille, '09, p. II ; cf. also Borge, '13, p. 37) he corrects this to read 'one axile chromatophore with one pyrenoid'. Lagerheim ('95, p. I5, foot-note 3) compares the chloroplast with that of Mougeotia, and a similar attitude is taken up by Bohlin ('01, p. $5^{\mathrm{I}}$ ). In their recent paper, West and Starkey ('15) come to the conclusion that in each cell of Zygnema evicetorum there is normally only one large axile chloroplast of indefinite outline. 'It is usually constricted in the middle and in some cases twisted. There are two large pyrenoids, one in each half of the chloroplast' (1. c., p. 205). These conclusions are based on a study of carefully fixed and stained material from various localities.

There can be no doubt that West and Starkey's conclusions are true for the ordinary aquatic and terrestrial forms, but they are certainly not applicable to the terrestrial form found at Hindhead. The chloroplasts are, in this case, quite often well defined in the living cell, and can be made to stand out very clearly by treatment with a 8 -10 per cent. solution of sodium chloride. In the shorter cells (Fig. I, G; Fig. 2, D) but a single chloroplast is present, generally with only one pyrenoid. The chloroplasts are, however, quite unlike those figured by West and Starkey, being more or less star-shaped and similar to those of other species of the genus Zygnema, although rather more massive, so that the stellate character is less pronounced (Fig. I). In the longer cells there are often two chloroplasts of this pattern, seemingly quite distinct and, if connected at all, the bridge between them must be exceedingly delicate (Fig. I, A, B). In other cases these longer cells showed an obvious connexion between the chloroplasts, but it should be pointed out that the individuality of the two portions of the chloroplast was much more sharply marked than is shown in West and Starkey's figures of the ordinary terrestrial form.

Cell-division was only observed in cells containing either two chloroplasts or a chloroplast that was already constricted into two very obvious portions. Each daughter-cell receives one of the two chloroplasts, so that for a time the young cell has but a single chromatophore (Fig. I, B-D). Sooner or later the chloroplast and pyrenoid gradually broaden out axially (Fig. 3, D) and the pyrenoid divides into two (Fig. I, E; Fig. 3, E). At this stage, therefore, the cells contain an elongated axial chloroplast with two pyrenoids, more or less widely separated. Finally, the elongated chloroplast becomes gradually constricted between the two pyrenoids (Fig. I, F) 
until in many cells, at the best, but a very narrow connecting bridge remains (cf. above). It would appear that as a general rule the segregation of the two chloroplasts is practically complete before a new septum arises.

A comparison of the above with West and Starkey's account (cf. also Fig. I with their Figs. I and 2) will show that the Hindhead form differs
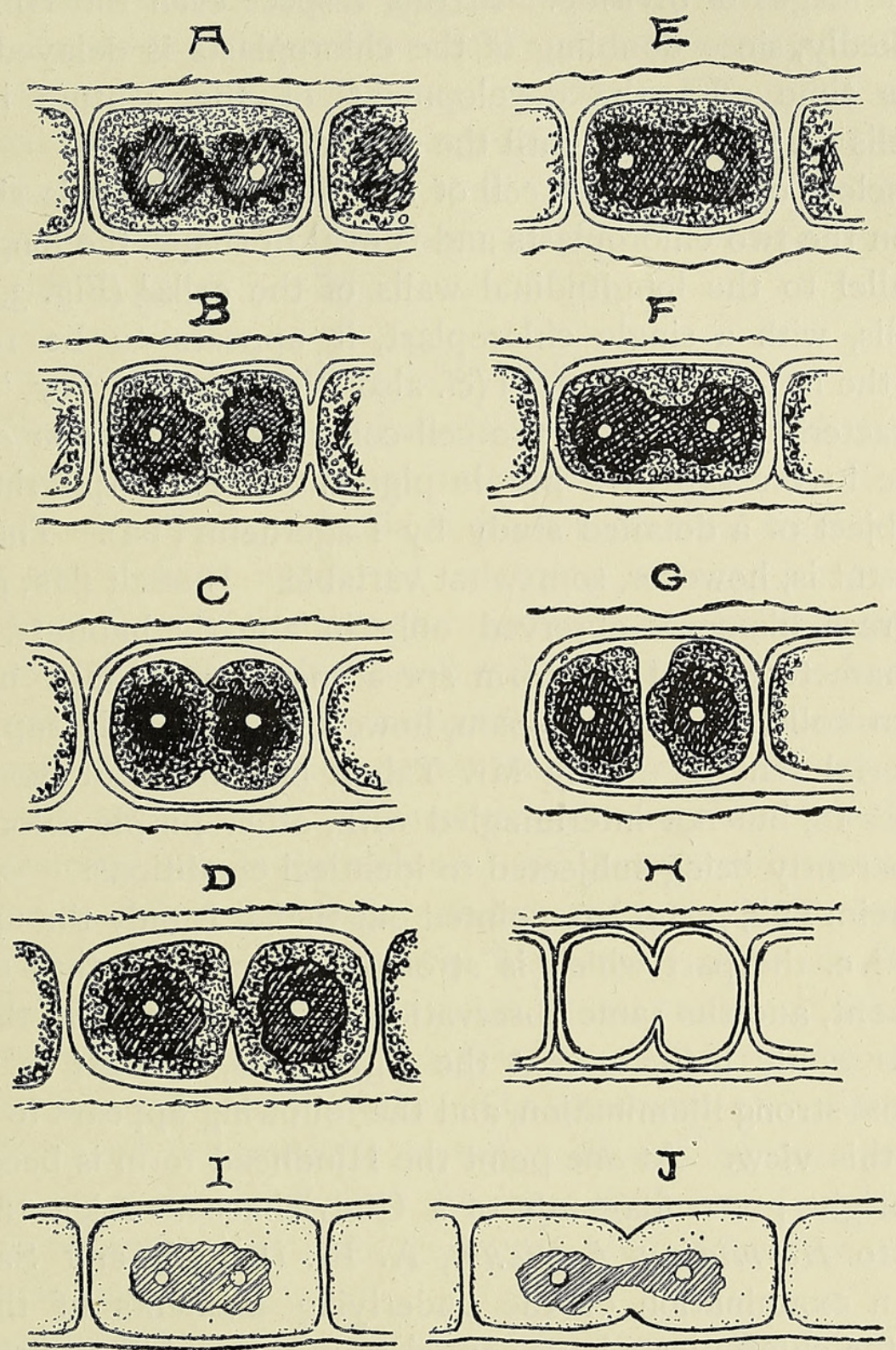

FIG. I. A-H, cell-structure and cell-division in the Hindhead form of Zygnema ericetorum; the drawings made from the living Alga. I-J, cells of the aquatic form, from Frensham; the drawings made from preserved material. For description, see text. (All figures $\times 8_{50}$.)

fundamentally from the ordinary type in two respects, viz. in the more definite shape of the chloroplasts, and in the frequent presence of two of them in the mature cell. It may be held by some that the differences are sufficiently pronounced to warrant the establishment of a distinct species, but I am not prepared at present to take up this attitude (see also p. I48). It may well be that observation of forms, like that at Hindhead, is 


\section{38 Fritsch.-The Morphology and Ecology of an Extreme}

responsible for the diverse views put forward by different authorities as to the nature of the chlorophyll-apparatus. The chloroplasts of the ordinary species of Zygnema are stated to divide at a time when the ingrowth of the septum between the daughter-cells is almost completed (de Bary, '58, p. II ; Wille, '90, p. I7), the young cell thus having two chromatophores except during early stages of division. In this respect even the Hindhead form differs markedly, since doubling of the chloroplasts is delayed until some considerable time after the development of the septum between the daughter-cells or, frequently, until the next division occurs.

The nucleus of the mature cell of the Hindhead form is situated midway between the two chloroplasts and is oval in shape, the long axis being placed parallel to the longitudinal walls of the cells ${ }^{1}$ (Fig. 3, C). In the younger cells, with a single chloroplast, it appears to be rounded and apposed to the latter (Fig. 3, D, E) (cf. also West and Starkey, '15, p. 197).

A characteristic feature of the cell-contents of Zygnema evicetorum is the presence in the sap of a purple pigment, phycoporphyrin, which has been the subject of a detailed study by Lagerheim ('95). The occurrence of this pigment is, however, somewhat variable. Hassall ('45, p. I75) refers to bright green filaments observed only in aquatic habitats, and purple filaments characteristic of the form spreading over swampy heaths. The aquatic form collected at Frensham, however, had purple sap, whilst part of the material sent to me by $\mathrm{Mr}$. Tabor had little or none, although growing close to, but not intermingled with, other purple-coloured masses, the two apparently being subjected to identical conditions.

Lagerheim ('95, p. 23) has pointed out that it is only the upper portion of a patch, i.e. the part which is strongly illuminated, that develops the purple pigment, and the same observation has been made on the Hindhead form. ${ }^{2}$ This would indicate that the pigment is, at least in part, a protection against strong illumination, and the following appears to lend further support to this view. At one point the Hindhead form is becoming overgrown by bright green filaments of a Ulotrichaceous Alga, that seems to correspond to Hormidium flaccidum, A. Br. (Fritsch and Salisbury, '15, p. I3I). An examination of the underlying filaments of the Zygnema shows that the chloroplasts have shifted from the middle to the upper sides of the cells, so that these appear green, in contrast to the purple-coloured under sides. It seems that, as a result of the screen formed by the Hormidium, the chloroplasts of the underlying Alga do not receive sufficient light, a disadvantage remedied by their moving to the upper sides of the cells. A patch of the typical purple-coloured Hindhead form was the Alga.

1 I am much indebted to my colleague, Dr. Salisbury, for kindly microtoming material of

2 The green filaments from the under side of the patch are excellent material for demonstrating the two massive chloroplasts of the mature cell. 
placed in the laboratory under a screen formed by a thick pad of cottonwool; after three days a considerable number of the threads showed a similar shifting of the chloroplasts to the upper sides of the cells, so that this movement is evidently readily accomplished.

The possibility of the pigment being related to the low temperature of the habitat was also considered by Lagerheim, but, in view of the abundant occurrence of Zygnema ericetorum in the Tropics, this explanation does not seem very plausible. On the other hand, as Bohlin ('01, p. 5I) suggests, its appearance may be connected with the extremes of temperature to which such a terrestrial Alga would be subjected. The phycoporphyrin may also be related in some way to the remarkable power of resistance to desiccation possessed by this Alga (cf. p. 145).

\section{B. The Cell-Wall.}

The cell-wall of the Hindhead form is thick and stratified, these features being more pronounced than is usual in the terrestrial form. Two or three regions are generally distinguishable in the longitudinal walls. The innermost layer is well defined, appearing in optical section as a bright line of varying thickness. Beyond this come successive strata, making up the greater part of the wall and forming what I will call the intermediate layer. These strata, which are not always easily recognized individually (although plainly seen in filaments placed in strong potash), appear progressively duller and duller the further out they lie. The manner of refraction of the light shows that the innermost layer is the densest, and that from there outwards the layers decrease in density, probably owing to gradual gelatinization (see below). In some cases the surface of the filament is quite smooth, but as a general rule the latter is bounded by a much interrupted dark line, composed of numerous adhering foreign particles (Fig. I). There is often more or less obvious constriction between the cells. On treatment with dilute sulphuric acid, the surface and intermediate layers swell and become lost to view, whilst the inner layer remains distinct for some little time longer. Addition of jodine, subsequent to the acid, gives the blue coloration of cellulose (cf. West and Starkey, '15, p. I94).

The same three layers are recognizable in the aquatic and ordinary terrestrial forms, but in both the intermediate layer is much thinner and, even in the latter, stratification is often unrecognizable without the application of special means. The surface is quite smooth.

The Hindhead form, if collected during a period of drought, consists of a hard brittle mass having an almost horny consistency. If a small portion be placed in a drop of water, it instantaneously softens and becomes exceedingly pliable. When a larger piece is brought into contact with water, swelling of the Alga is macroscopically visible, and if the quantity of water be small, the bulk of it is immediately absorbed, far more rapidly 
than by a piece of filter-paper of equivalent size. These phenomena are due to the fact that the greater part of the thick wall is mucilaginous, so that the dry filament swells up very considerably on wetting. Thus, the average width of the dry threads is $16 \mu$, of the wet threads $24 \mu$; the average thickness of the longitudinal walls of dry filaments (examined in spirit) is $2 \cdot 3 \mu$, of wet filaments $5 \mu$.

It does not appear that the inner layer of the wall is at all appreciably mucilaginous, since it retains its outline and normal appearance, even in dry threads. On the other hand, the intermediate layer must be very largely gelatinous in character in the Hindhead form, as it is very much shrunken and often quite thin in the dry filament. In all probability the mucilaginous character increases from the interior towards the outside, the surface layer being very strongly mucilaginous (cf. above).

The advantage of this mucilaginous wall to the Hindhead Alga is obvious. It not only involves a very rapid recovery of the cells, when supplies of moisture become available, but, since the gelatinous walls will only part with their water by slow degrees, the full effects of a drought will only be felt by the Alga some time after dry weather sets in. It is indeed astonishing how long the desiccated filaments still retain their soft flexible character. Moreover, at certain periods of the year, although exposed to intense insolation in the daytime, such a form will be able to make use to the full of the dew deposited at night, so that even during periods of drought it may be able to hold its own to some extent. In short, we see in this character a pronounced adaptation to the conditions of the habitat. In the material of the ordinary terrestrial form at my disposal, the intermediate layer was generally much thinner and did not appear to be appreciably mucilaginous. .

A considerable number of aquatic Zygnemaceae form gelatinous sheaths about their filaments, but these are sharply marked off from the cell-wall, and there is reason to believe that they are composed of mucilage excreted from the cell-contents (Klebs, '86, p. 368) and not, as in the Hindhead form, a product of the membrane. West and Starkey ('15, p. 194) record the presence of an occasional more or less distinct gelatinous sheath in $Z$. evicetorum, but I have never met with anything of the kind in the Hindhead form. Thick and stratified mucilaginous membranes are, on the other hand, frequently found in the resting-cells (akinetes) formed, as a result of desiccation, by many species of Zygnema (Z. leiospermum, Z. pectinatum) (de Bary, '58, pp. 9, 10), so that it might be said of the Hindhead Alga that it existed permanently in the akinete condition.

The development of the septum between two daughter-cells is initiated by an annular invagination of the innermost layer of the wall, about midway between the two chloroplasts or the two halves of the chloroplast (Fig. I, B). It often has the appearance as though this were due to 
a gradual thickening of the intermediate layer pushing in the inner layer at this point. The invagination slowly progresses towards the centre (Fig. I, C, D), thus gradually constricting the protoplast in the manner customary among the simpler Algae. It does not seem, however, that a complete septum is at once formed, the two daughter-cells remaining for some time connected by a more or less narrow pore (Fig. I, D, H), which probably ultimately closes. In optical section the continuity of the two protoplasts is often readily recognized. The septum at its first initiation is not a uniform structure, but exhibits three layers meeting in a point at the inner edge of the annular invagination. Two of these layers, forming the limbs of a V, are continuous with the innermost layer of the longitudinal wall, whilst the third lies between them and appears to be similar in nature to the intermediate layer (cf. especially Fig. I, H).

In many of the filaments of the Hindhead form one observes pairs of daughter-cells in which the one protoplast is prominently beaked towards that of the other cell, even when seen in surface view (Fig. I, G; Fig. 2, G). This phenomenon is a result of the frequent asymmetry of the ingrowing septum. The latter, in optical section, either appears symmetrical and V-shaped (Fig. I, B, C) or its two edges are asymmetrical (as in Fig. I, D, G), the one being generally placed at right angles to, the other at an obtuse angle to, the longitudinal wall. It has not been possible to find any underlying reason for the development of these asymmetrical septa, which are very commonly observed.

\section{The Reaction to Drought on the Part of the HindheAd Form (Fig. 2).}

The appearance of a mature filament of the Hindhead form is a definite expression of the alternating periods of drought and rainfall which follow one another in the habitat. On the arrival of a dry period the protoplast, probably shrinking slightly and mostly rounding off to a more or less oval or spherical shape, according to the previous form of the cell, generally excretes a new layer of membrane on its outer surface and contiguous to the inner layer above described (p. I39). The latter often seems at the same time to lose in definition and gradually to become merged in the intermediate layer, but this does not necessarily occur; particularly in thickwalled filaments the former inner layer may persist for some time as a definite stratum in the intermediate layer.

The septa also generally lose their sharp definition and, as the new membrane develops on either side, the substance composing them becomes gradually indistinguishable from the intermediate layer of the longitudinal walls, which now therefore extends uniformly all round the cell (Fig. I, A ; Fig. 2, F). Except for the development of the new layer of membrane and 


\section{Fritsch.-The Morphology and Ecology of an Extreme}

the moderate rounding off of the protoplast, no changes seem to be connected with the production of these 'akinetes' (cf., however, below); the chloroplast or chloroplasts, as the case may be, are still recognizable and

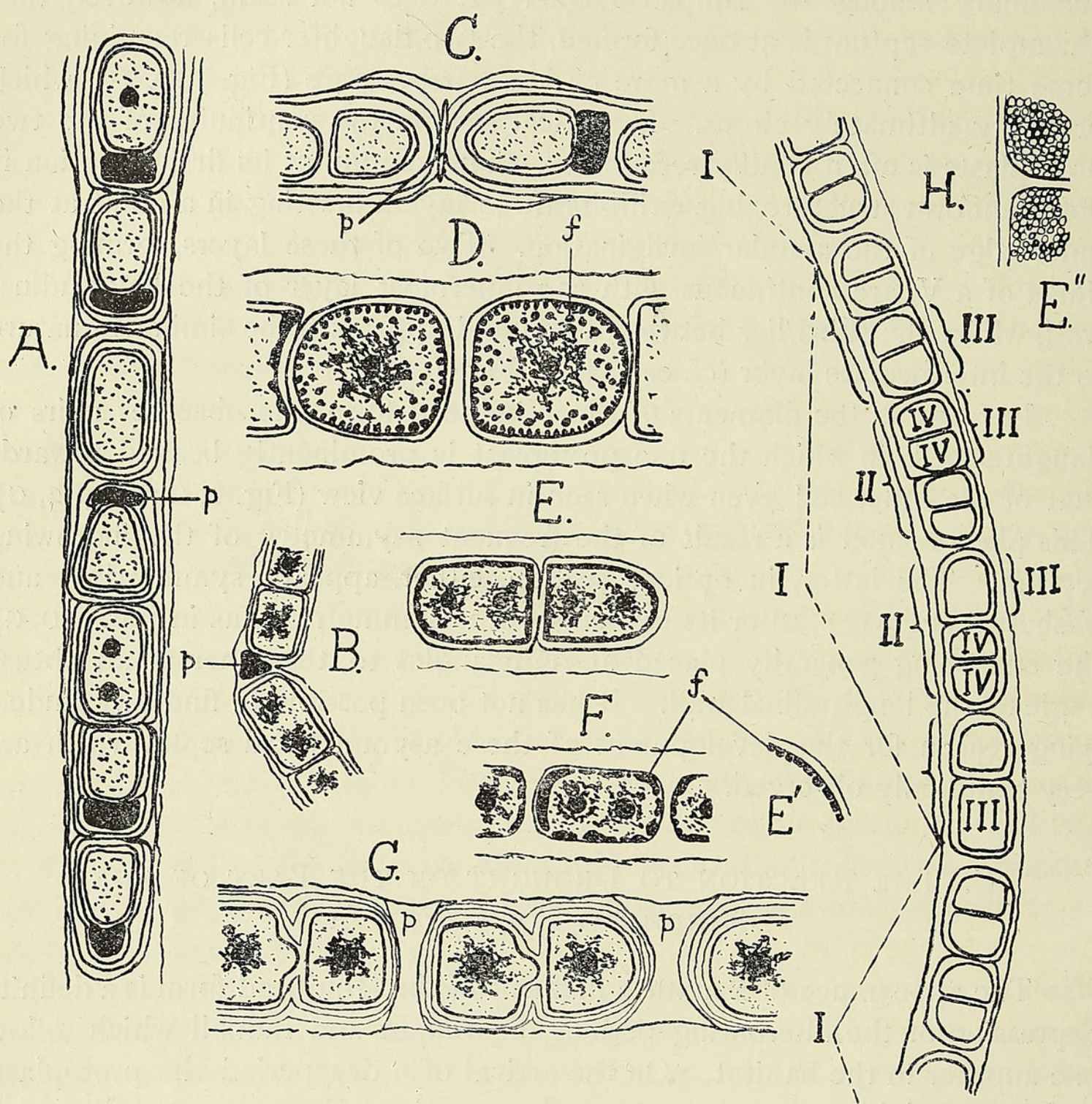

FIG. 2. Terrestrial form of Zygnema ericetorum from Hindhead. A, formation of akinetes and pigment-cells (the latter in black). B, impending rupture of a filament at a point where a pigmentcell is situated. C, obliteration of an empty pigment-cell by growth of adjacent akinetes. D, ordinary cells of the Hindhead form, showing the disposition of the fat-globules. E, cells of a filament that has been subjected to desiccation, showing the dense peripheral layer of fat-globules. $\mathrm{E}^{\prime}$, small part of one of these cells, in optical section. $\mathrm{E}^{\prime \prime}$, ditto, in surface view. F, cells of a dry filament, showing the large peripheral fat-masses that are sometimes found. G, filament, showing divided akinetes and empty pigment-cells. $\mathrm{H}$, diagram of a filament showing the products of successive akinetes, I, II, III, IV. p., pigment-cell ; f., fat. (B and $\mathrm{H}, \times 400 ; \mathrm{A}, \mathrm{C}, \mathrm{E}, \mathrm{E}^{\prime \prime}, \mathrm{F}, \times 6_{50}$; D and G, $\times 850 ; \mathrm{E}^{\prime} \times \mathrm{I} 200$.)

the purple-coloured sap appears unaltered. The response to drought is thus of a very simple kind.

With a return of more favourable conditions, moisture is rapidly absorbed, as described above. The filament immediately resumes its normal appearance, and cell-division sets in sooner or later. If the akinete 
was produced from a mature cell with two chloroplasts, a formation of daughter-cells may take place almost immediately. If, on the other hand, the akinete was formed soon after a cell had divided, so that it contained but one chloroplast, division may be considerably delayed. The septa cut the akinetes into two approximately equal halves and, since the adjacent faces of the daughter-protoplasts are more or less flat, whilst their distal faces are often rounded off, the pairs of protoplasts produced from a single akinete, as the result of division, frequently recall the two halves of a Cosmarium-cell (Fig. 2, H). In this way the products of division of the individual akinetes of each filament are quite plainly distinguishable.

The two daughter-cells may divide once more, this depending on how soon the first division sets in after the arrival of favourable conditions. Thus we may get groups of four cells (Fig. 2, H, II) developed, before a fresh drought causes renewed rounding off and fresh akinete formation. I have never observed more than four cells thus produced from a single akinete, during the interval between one drought and another.

The repeated formation of akinetes, involving each time the apposition of a new layer of membrane on the inner side of the cell-wall, leads to a gradual thickening of the latter, mainly noticeable in the transverse septa. In examining a given length of filament, strongly thickened septa are found at more or less remote intervals (Fig. 2, H, I). Between these one meets with septa of varying thickness, some quite thin and recently formed, others already more or less thickened and of older date (Fig. 2, H, II, III, IV). The region lying between two strongly thickened septa is the product of a single akinete of a remote generation; the intervening cells can be grouped, on the same principle, into smaller and smaller sets formed from more and more recently produced akinetes. In this way, by a careful scrutiny, it is often possible to estimate roughly the number of periods of drought to which a given filament has been subjected (Fig. 2, H). The longitudinal walls do not appear to increase much in thickness beyond a certain stage, since the outermost layers gradually merge into mucilage (cf. above).

In the cells of the filaments of the Hindhead form, numerous small globules, of irregular shape and varying size, are found distributed, more particularly in the peripheral part of the protoplast (Fig. 2, D). I have not observed such globules in the aquatic form, and in the terrestrial form from Wales they occur in much smaller numbers and are, on the average, much coarser (cf. also West and Starkey, '15, p. I97). When threads of the Hindhead form are subjected to gradual desiccation, an exceedingly dense layer of small and rather uniform globules appears in immediate contact with the inner layer of the cell-wall, whilst relatively few are found in the rest of the protoplast (Fig. 2, E, E'). The peripheral layer of globules is so dense and so closely apposed to the cell-wall that it looks like a second 


\section{I44 Fritsch.-The Morphology and Ecology of an Extreme}

pitted membrane in optical section (Fig. 2, $\mathrm{E}^{\prime}$ ) and gives a characteristic mottled appearance to the protoplast in surface view (Fig. 2, $\mathrm{E}^{\prime \prime}$ ). If such dried filaments are kept in water for a few hours, this distinctive arrangement of the globules becomes less pronounced. They no longer form such a dense continuous layer in all the cells, nor are they quite so closely adpressed to the cell-wall, although they still occupy in the main the peripheral protoplasm (Fig. 2, D). The filaments, subjected to dryness, when first placed in water, appear more transparent than after being immersed for some time, and this loss in transparency is probably due to the much more irregular distribution of the globules in the second case. Not only does the arrangement of the globules become less regular in filaments immersed in water, but it appears that they also undergo increase in size, perhaps accomplished by coalescence of the smaller ones. Lastly, it was found that in threads which had been subjected to prolonged drought, the globules in many of the cells were partly replaced by one or more highly refractive masses of considerable size, again located in the periphery of the protoplast (Fig. 2, F).

De Bary ('58, p. 10; P1. I, Figs. 16, 20) has already described such globules in the resting-cells of other species of Zygnema, and refers to them as fat-bodies. Their reactions with osmic acid and tincture of alkanna, as well as their solubility in chloroform, are quite in accordance with this view (cf. West and Starkey, '15, p. I98). De Bary does not deal with the varying disposition of the fat-globules in dry and moistened filaments, but, seeing that these resting-cells are very similar to those of the Hindhead form, it is probable that they might show the same phenomena.

When cells, whether of the dry or wet filaments, are plasmolysed by immersion in a strong solution of sodium chloride, the globules in question become altogether lost to view. When the plasmolysed cells are allowed to recover by placing the threads in water, the globules again become visible; in many of the cells they do not appear to have undergone any change, but in some they are not quite as densely arranged as before. Plasmolysis does not appear to be effected by anything less than an 8 per cent. solution of salt, and, with this strength, but a very slight separation of the protoplast from the cell-membrane takes place. In stronger solutions (e. g. IO-I 2 per cent.) some of the cells become more markedly plasmolysed, a very obvious contraction of the protoplast taking place, but it requires a I5 per cent. solution to produce marked plasmolysis in all the cells. As far as I have been able to determine, there is no difference between the dry and wet filaments in these respects. Attention may be called to the very high osmotic pressures manifested by the cell-sap in this Alga.

The fact that the peripheral layer of fat-globules remains more or less intact, after recovery from plasmolysis, would indicate a fair degree of stability. Whenever there is a shrinkage of the protoplast, such as probably 
occurs to a slight extent when the threads are exposed to drought, the smaller surface area of the protoplasm must lead to a still closer crowding of the peripheral layer of fat-globules. If we could imagine that this contraction brought about a coalescence of the individual fat-bodies, a continuous layer of fat would be formed on the surface of the protoplast and this would act as a kind of macintosh to the latter, tending to prevent evaporation from the cell. But such a coalescence is unlikely on physical grounds, and moreover, if it occurred, it would be difficult to understand how the peripheral layer came to consist of numerous minute separate globules the moment the dry filament was placed in water. For the present, therefore, the function of this peripheral fat-layer must remain unsolved, although its extreme development, especially in the cells of the dry threads, will dispose one to associate it in one way or another with the great power of resistance to drought possessed by the form under discussion.

This power is displayed not only by the instantaneous recovery of the filaments, when placed in water, even after many months of desiccation, but also by the fact that there does not appear to be any appreciable difference in osmotic pressure between the cells of dry filaments and of those growing under moist conditions. Material collected at Hindhead was kept for five months in part dry, in part moist. At the end of this time it was found that there was no difference between the two sets as regards the number of living cells in the threads.

According to Lagerheim ('95, p. 24) the cells of the filaments of $Z$. ericetorum, on being subjected to desiccation, become filled with reserve substances and thicken their walls, whilst the phycoporphyrin disappears; as a consequence the resting-cells are almost colourless. In the case of the Hindhead form, although it has been collected at many different times of the year, such akinetes have never been observed; in fact, the cells of the resting threads are coloured just as deep a purple as those of the active filaments. It is plain therefore that the state of affairs described by Lagerheim is not an essential consequence of drying up.

On the other hand, a modification of the ordinary response to desiccation has been observed in material of the Hindhead form collected in the early part of the year, and here a certain reduction in the amount of pigment may possibly take place. In this case, the contents of most of the cells had divided unequally into a large akinete and a small cell, apparently provided with relatively little protoplasm, but filled with deep purple sap; the pigment-cell formed a kind of cap over the end of the adjacent akinete and was cut off from it by a delicate wall (Fig. 2, A). The pigment-cells were either produced on the same side over a considerable length of filament or no such regularity was apparent (Fig. 2, A) (cf. West and Starkey, '15, p. 199, Fig. 2, C). As a general rule the akinetes were more or less pointed 
towards the pigment-cells, whilst their distal ends were rounded or almost truncate (Fig. 2, A), and it will be noticed that these akinetes were provided with an especially thick and stratified membrane.

Since this mode of akinete formation was observed mainly in winter, it is possible that the extrusion of purple sap into the pigment-cell, by reducing the water-content of the protoplast of the akinete, renders it more resistant to frosts, to which in the exposed habitat it must be very liable. This explanation is, however, only advanced tentatively, since the phenomenon may be due to other causes, but attention should be drawn to the

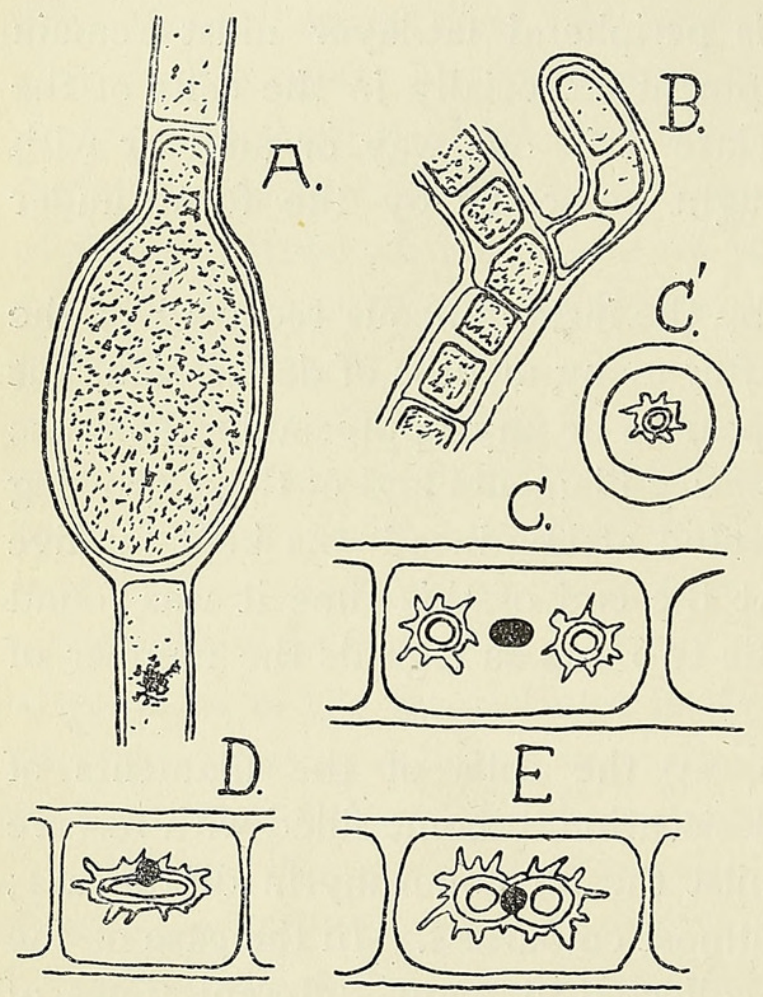

FIG. 3. A, swollen akinete of terrestrial form from Wales. B-E, terrestrial form from Hindhead. $\mathrm{B}$, rhizoid-formation. C-E, cells from microtomed material of the Hindhead form; $\mathrm{C}-\mathrm{E}$ in longitudinal section; $\mathrm{C}^{\prime}$ in transverse section. $\mathrm{C}$, a mature cell. $\mathrm{D}$ and $\mathrm{E}$, stages in division of the chloroplast. The nucleus is shown black. (A and $\mathrm{B}, \times 400 ; \mathrm{C}-\mathrm{E}, \times 6_{50}$.)

fact that it was observed in the bulk of the filaments over a considerable area. On a much smaller scale it has also been encountered at other times of the year, but only with reference to occasional akinetes.

As above indicated, the division leading to the production of akinete and pigment-cell is an unequal one and due to the development of a septum, generally of the asymmetrical type (p. I4I), towards one end of the cell. In fact, the asymmetry of the septum is responsible for the usual pointed shape of theakinete at the end adjacent to the pigmentcell. When renewed growth takes place, the contents of the latter gradually disintegrate and disappear, so that sooner or later the pigmentcell is quite empty (Fig. 2, G).

These empty cells constitute so many weak points in the filaments, at which rupture readily takes place, and therefore this mode of akinete formation probably brings with it the advantages of extensive vegetative propagation (cf. Fig. 2, G). As a matter of fact, many of the filaments of the Hindhead form terminate in short empty fragments of cell-membrane appearing just like the ruptured remnants of pigment-cells. In some cases, however, the adjacent akinetes, on resuming growth, protrude from either side into the empty pigment-cell, so that the cavity of the latter becomes more or less obliterated, and ultimately appears only as a narrow slit in the thick membrane between the two (Fig. 2, C).

The dying away of occasional cells of a filament is not confined to 
these special pigment-cells, being not uncommon at all times of the year (cf. West and Starkey, '15, p. 198). The cells in question generally appear deeply pigmented at first and, as indicated in Fig. 2, B, constitute points at which the filaments readily give way. In many cases rupture is delayed until the contents have completely disappeared. Apart from such isolated cells, it occasionally happens that large numbers of the cells of a thread die away, leaving healthy akinetes only here and there, separated by more or less extensive stretches of dead filament. The akinetes in such threads are generally well rounded and provided with a very defined layer of the peripheral fat-globules. No doubt they ultimately become free and give rise to new threads.

Mention may be made at this point of a peculiar form of akinete, rarely observed in the material from Wales (Fig. 3, A). In this case the greater part of the cell had swollen up very considerably, this distension however not affecting the last quarter of the cell, so that the resulting shape rather recalled the oogonia of some Oedogoniums. The wall was rather strongly thickened and stratified, and the cell-contents, though appearing perfectly healthy, were so dense as to make it impossible to decipher any details of structure. Nothing corresponding to these swollen cells has been observed in the remaining material. Apart from such elements, no akinete formation was observed in the material from Wales.

\section{Comparison of the Hindhead Form with the Aquatic and ORDINARY TERRESTRIAL TYPES.}

A part from the chloroplasts which have already been fully considered (p. 136$)$, the Hindhead Alga differs from the ordinary terrestrial form of Zygnema ericetorum in the length of the cells, the degree of thickening of the walls, and the abundance of the fat-globules. The following table shows the relative dimensions of the Hindhead form, the form from Wales, and the aquatic one:

$\begin{array}{lccc} & \begin{array}{c}\text { Terrestrial form, } \\ \text { Hindhead. }\end{array} & \begin{array}{c}\text { Aquatic form, } \\ \text { Frensham. }\end{array} & \begin{array}{c}\text { Terrestrial form, } \\ \text { Wales. }\end{array} \\ \text { Length of cell . . . . . . } & 26.5 \mu(24-30) & 40 \mu(34-48) & 3 \mathrm{I} \cdot \mathrm{I} \mu(2 \mathrm{I}-4.8) \\ \text { Width of cell . . . . . } & 25.5 \mu(24-27) & \text { I9 } \mu(\mathrm{I} 6-2 \mathrm{I}) & 24 \cdot 2 \mu(23-26) \\ \text { Thickness of longitudinal walls } & 5 \mu(4-6) & \mathrm{I} \cdot 8 \mu(\mathrm{I} \cdot 5-2) & 3 \mu(2-3 \cdot 5)\end{array}$

It should be mentioned here that the form from Wales is perhaps not quite typical of the true terrestrial Alga, since it occurred in the immediate neighbourhood of numerous small streams which are practically never dry. As contrasted with the conditions obtaining at Hindhead, such a form would be very advantageously situated. It can scarcely be doubted that the extreme shortness of the cells of the Hindhead form is a result of the brief periods during which growth is alone possible.

1 The figures in round brackets give the extreme dimensions. 
Two other features are generally cited as characteristic of the terrestrial form, viz. the frequent swollen shape of the cells and the formation of short rhizoids (Borge, '13, p. 37 ; Collins, '09, p. I 20). As regards the first point, I have been unable to find any marked difference between the three forms in the shape of the cell, which varies between cylindrical and somewhat barrel-shaped. The rhizoids, which may be uni- or multicellular (Fig. 3, B), have been encountered only in the two terrestrial forms.

To raise once again the question of the possibility of the Hindhead Alga being a separate species, it may be pointed out that, except for the chloroplasts, all the distinctive features appear merely as intensifications of the characters of the ordinary terrestrial form. As for the chloroplasts, the greater degree of independence of the two halves may be a result of the very slow growth of the Hindhead form and the consequent long intervals between successive cell-divisions. In short, I am inclined to regard the Hindhead Alga merely as a very extreme xerophytic form of Zygnema ericetorum.

\section{E. Summary.}

An extreme terrestrial Alga is described, probably belonging to Zygnema ericetorum and owing its peculiarities to the extremely inhospitable habitat on the Hindhead Common. The mature cell of this form contains two chloroplasts, much like those of other species of Zygnema, although they may hang together by an exceedingly narrow connecting bridge. For some time after division but a single chloroplast is found in each daughtercell. Division is accomplished by the gradual invagination of the innermost layer of the cell-wall, but it appears that the septum thus formed is not completed for some time, a central pore remaining through which the daughter-protoplasts stand in connexion with one another. Two or three layers are distinguishable in the longitudinal walls.

The Hindhead Alga may be said to be permanently in the akinete condition, its cells agreeing in many respects with the akinetes of such forms as $Z$. leiospermum, $Z$. pectinatum, \&c. The outer portion of the wall is strongly thickened and mucilaginous, and is shown to play a great part in protecting the cells during periods of drought and in bringing about a rapid recovery on the reappearance of favourable conditions. The cells contain numerous fat-globules (Fig. 2, D), which, on the commencement of desiccation, form an exceedingly dense layer closely apposed to the inner surface of the membrane (Fig. 2, E, E') ; the function of these globules is not exactly clear. Some hours after moistening the dry filaments, the regular peripheral disposition of the fat-globules more or less disappears.

With the advent of a dry period the protoplasts round off slightly and develop a new layer of membrane. The products of division of successive akinetes (i.e. the growth during the intervals between two periods of 
drought) are plainly distinguishable and show that, as a general rule, each cell divides at the most but twice between two successive dry periods (Fig. 2, H). A part from the ordinary mode of response to drought, a second method of akinete formation has been observed in the early part of the year; in this the cells undergo unequal division, resulting in the formation of an akinete and of a much smaller pigment-cell (Fig. 2, A). The contents of the pigment-cells subsequently disappear, and the empty cells form weak points at which rupture of the threads readily occurs.

Attention is drawn to the extreme adaptation of this form to drought. The recovery of the dry filament is practically instantaneous when placed in water, there is no marked difference between the osmotic pressure of moist threads and those subjected to dryness, and there is no greater percentage of dead cells in filaments that have been kept dry for months than in those that have been in water for the same length of time.

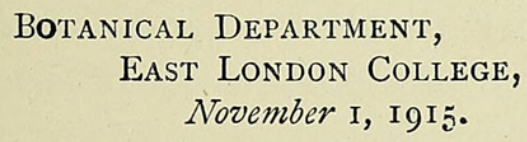

BOTANICAL DEPARTMENT, EAst London College, November I, I9I5.

\section{LITERATURE CITED.}

1. Bohlin, K. ('01): Étude sur la flore algologique des Açores. Bih. till K. Sv. Vet.-Akad. Handl., xxvii, Afd. iii, No. 4, I90I.

2. Borge, O. ('13): Zygnemaceae. Die Süsswasserflora Deutschlands, Oesterreichs u. d. Schweiz. Heft ix, I9I3.

3. Collins, F. S. ('09): The Green Algae of North America. Tufts College Studies, Scient. Ser. ii, 1909.

4. DE BARy ('58): Unters. über die Familie der Conjugaten. Leipzig, I858.

5. DE Wildeman ('97): Algues rapportées par M. J. Massart d'un voyage aux Indes Néerlandaises. Ann. Jard. Buitenzorg, I ${ }^{\text {er }}$ Suppl., I 897 .

6. Fritsch, F. E., and Salisbury, E. J. ('15): Further Observations on the Heath Association on Hindhead Common. New Phytol., vol. xiv, I9I 5.

7. Hassall, A. H. ('45): A History of the British Freshwater Algae. London, vol. i, 1845.

8. Klebs, G. ('86) : Ueber d. Organisation d. Gallerte bei einigen Algen u. Flagellaten. Unters. d. Bot. Inst. Tuibingen, ii, I886.

9. Lagerheim, G. ('95) : Ueber das Phycoporphyrin, einen Conjugatenfarbstoff. Videnskab.-Selsk. Skrifter, I. Mat.-nat. Kl., I 895 , No. 5 .

10. Schmitz ('83) : Die Chromatophoren der Algen. Verh. d. nat. Ver. d. preuss. Rheinl. u. Westfalens, $x l, 1883$.

11. West, G. S., and Starkey, C. B. ('15): A Contribution to the Cytology and Life-history of Zygnema ericetorum (Kuetz.), Hansg., \&c. New Phytol., vol. xiv, I9I5.

12. Wille, N. ('90): Zygnemaceae. In Engler and Prantl, Die natürl. Pflanzenfam., I. Teil, 2. Abt., I 890 .

13. ('09): Zygnemaceae. Op. cit., Nachtr. z. I. Teil, 2. Abt., I909. 


\section{$2 \mathrm{BHL}$ Biodiversity Heritage Library}

Fritsch, Felix Eugene. 1916. "The morphology and ecology of an extreme terrestrial form of Zygnema (Zygogonium) ericetorum (Kuetz.), Hansg." Annals of botany 30, 135-149.

https://doi.org/10.1093/oxfordjournals.aob.a089580.

View This Item Online: https://www.biodiversitylibrary.org/item/237452

DOI: https://doi.org/10.1093/oxfordjournals.aob.a089580

Permalink: https://www.biodiversitylibrary.org/partpdf/320102

\section{Holding Institution}

Smithsonian Libraries

\section{Sponsored by}

Biodiversity Heritage Library

\section{Copyright \& Reuse}

Copyright Status: Not in copyright. The BHL knows of no copyright restrictions on this item.

This document was created from content at the Biodiversity Heritage Library, the world's largest open access digital library for biodiversity literature and archives. Visit BHL at https://www.biodiversitylibrary.org. 